\title{
Nutritional diversity of agricultural and agro-industrial by-products for ruminant feeding
}

[Diversidade nutricional de subprodutos agrícola e agro-industrial para alimentação de ruminantes]

\author{
J.A.G. Azevêdo ${ }^{1}$, S.C. Valadares Filho' ${ }^{2}$, D.S. Pina ${ }^{3}$, E. Detmann ${ }^{2}$, L.G.R. Pereira ${ }^{4}$, \\ R.F.D. Valadares ${ }^{2}$, H.J. Fernandes ${ }^{5}$, L.F. Costa e Silva ${ }^{2}$, P.B. Benedeti ${ }^{2}$ \\ ${ }^{1}$ Universidade Estadual de Santa Cruz - Ilhéus, BA \\ ${ }^{2}$ Universidade Federal de Viçosa, Viçosa, MG \\ ${ }^{3}$ Universidade Federal do Mato Grosso do Sul - Cuiabá, MT \\ ${ }^{4}$ Embrapa Gado de Leite - Coronel Pacheco, MG \\ ${ }^{5}$ Universidade Estadual do Mato Grosso do Sul - Dourados, MS
}

\begin{abstract}
Fifty-seven by-products were collected from regions throughout Brazil. Chemical composition, in vitro neutral detergent fiber digestibility (IVNDFD), and total digestible nutrients (TDN) were determined with the objective of grouping by-products with similar nutritional characteristics. The by-products belonging to group one (G1) presented the highest content of neutral detergent fiber exclusive of ash and nitrogenous compounds [aNDFom(n)] and lowest energy content, with $42.5 \%$ and $38.8 \%$ of IVNDFD and TDN, respectively. A new cluster analysis was carried in order to better characterize G2 by-products, six subgroups (SGs) were established (SG1 to SG6). SG1 by-products had the highest and the lowest values for lignin and TDN, respectively. SG2 by-products had the highest aNDFom(n) value, with TDN and IVNDFD values greater than 600 and $700 \mathrm{~g} / \mathrm{kg}$, respectively, and crude protein (CP) value below $200 \mathrm{~g} / \mathrm{kg}$ in dry matter (DM). Among all the subgroups, SG3 had the highest TDN $(772 \mathrm{~g} / \mathrm{kg}$ ) and IVNDFD $(934 \mathrm{~g} / \mathrm{kg})$ values and the lowest lignin $(23 \mathrm{~g} / \mathrm{kg}$ in DM) value. The ether extract was what most influenced the hierarchical establishment of residual grouping in SG4. SG5 by-products had the highest concentration of non-fibrous carbohydrate. Different from the other subgroups, SG6 by-products had the highest value of available CP.
\end{abstract}

Keywords: alternative feed, nutritive value, residues, waste

\section{RESUMO}

Cinquenta e sete subprodutos foram coletados de diferentes regiões do Brasil. Foram determinados a composição química, a digestibilidade in vitro da fibra em detergente neutro (DIVFDN) e os nutrientes digestiveis totais (NDT), com o objetivo de agrupar os subprodutos com características nutricionais semelhantes. Os subprodutos pertencentes a um grupo (G1) apresentaram maior conteúdo de fibra em detergente neutro corrida para cinzas e compostos nitrogenados (FDNcp) e menor teor energético, e tinham 42,5\% e 38,8\% de DIVFDN e NDT, respectivamente. Uma nova análise de cluster foi realizada no intuito de melhor caracterizar os subprodutos do G2; seis subgrupos (SG) foram estabelecidos (SG1 a $S G 6)$. Os subprodutos SG1 tiveram os maiores e os menores valores de lignina e NDT, respectivamente. Os subprodutos SG2 tiveram o maior valor de FDNcp, com valores de NDT e DIVFDN acima de 600 e $700 \mathrm{~g} / \mathrm{kg}$, respectivamente, e de proteína bruta (PB) abaixo de $200 \mathrm{~g} / \mathrm{kg}$ de matéria seca (MS). Entre todos os subgrupos, SG3 tiveram os maiores valores de NDT $(772 \mathrm{~g} / \mathrm{kg})$ e DIVFDN $(934 \mathrm{~g} / \mathrm{kg})$ e o menor valor de lignina (23g/kg de MS). O extrato etéreo foi o que mais influenciou no estabelecimento hierárquico de agrupamento em SG4. Os subprodutos SG5 tinham maior concentração de carboidratos não fibriosos. Diferentemente dos demais subgrupos, subprodutos SG6 tinham o valor mais elevado de PB disponível.

Palavras-chave: alimentos alternativos, valor nutritivo, resíduos, perdas

Recebido em 16 de março de 2011

Aceito em 24 de maio de 2012

E-mail: augustog@uesc.br

Apoio financeiro: CNPq/ CT-AGRO/MCT, FAPEMIG e FAPESB 


\section{INTRODUCTION}

Brazilian agribusiness data obtained by the Brazilian Confederation of Agricultural and Livestock of the University of São Paulo in 2007 reported a crop record of 131.5 million tons of grain, contributing approximate revenue of US\$ 359.9 billion to the gross domestic product (Cieglinski, 2008).

In spite of the optimistic growth of Brazil's agribusiness and its importance to the Brazilian economy, the quality and diversity of generated agricultural and agro-industrial by-products are a concern because its volume is proportional to the agribusiness growth.

One Brazilian estimate, based on 2002/2003 crop data, indicated a waste of 32 million tons of food between production to final consumer, or, in other words, an approximate loss of $150 \mathrm{~g} / \mathrm{kg}$ of the total feedstuff of grains, fruits, vegetables, and animal products produced (CNPq, 2005).

Furthermore, these feedstuffs are not only natural resource losses, when stored in inadequate places they can also lead to serious environmental contamination, mainly of water and soil resources.

Ruminants play a valuable role in sustainable agricultural systems since they are capable of converting renewable natural resources, such as agricultural and agro-industrial by-products, into high quality feed for man (Oltjen and Beckett, 1996).

It is within this context that research on the quality and viability of agricultural and agroindustrial by-products and their use as alternative feed has grown world-wide. However, due to lack of current data, particularly in regard to nutritional value in the alternative feed, the aim of this present study was to estimate the chemical composition, the in vitro neutral detergent fiber digestibility (IVNDFD), the energy value, and the characterization of agricultural and agroindustrial by-products with cluster analysis.

\section{MATERIALS AND METHODS}

This study was carried out in the Animal Science Department of the Center of Agrarian Sciences of the Federal University of Viçosa, Viçosa, MG, Brazil.

Fifty-seven samples of agricultural and agroindustrial by-products were collected from different regions throughout Brazil (African oil meal, Manufactures of soap (palm), Palm meal Elaeis guineensis; Barbados cherry juice residue - Malpighia glabra; Brewer residue - Hordeum vulgare; Carrot discard human residue, Carrot leaf , Carrot shaving, Carrot thick residue Daucus carota; Cassava flower processing, Cassava foliage, Cassava hull, Cassava hull dirty, Cassava hull thread, Cassava leaf, Cassava shaving, Cassava stalk - Manihot esculenta; Castor bran, Castor detoxicated bran - Ricinus communis; Citrus pulp - Citrus sinensis; Cocoa eed hull, Cocoa meal - Theobroma cacao; Coffee hull, Coffee parchment - Coffea arábica; Cotton bran, Cotton seed - Gossypium hirsutum; Cracked bean - Phaseolus vulgaris; Cracker meal - Triticum vulgare; Genipap juice residue Genipa americana; Grape wine residue - Vitis labrusca; Guava juice residue - Psidium guajava; Jack fruit, Jack fruit silage Artocarpus heterophyllus; Mango hull, Mango internal seed, Mango juice residue, Mango outward seed - Mangifera indica; Papaya juice residue, Papaya seed, Papaya without seed Carica papaya; Passion fruit - Passiflora ligulari, Peach palm - Bactris gasipae; Pearl millet - Pennisetum americanum; Pineapple crown, Pineapple hull, Pineapple juice residue Ananas comosus; Protein bran - Zea mays; Pumpkin seed - Cucúrbita moschata; Radish biofuel residue - Raphanus sativus; Rice hull Oryza sativa; Soursop juice residue - Anona muricata; Soybean hull - Glycine Max; Sunflower biofuel residue - Helianthus annuus; Tamarind juice residue - Tamarindus indica; Uricury bran - Syagrus coronata; Wild cabbage residue, Wild cabbage stalk - Brassica oleracea).

The agricultural and agro-industrial by-products were oven dried at $55^{\circ} \mathrm{C}$ for 48 hours, bulked, sampled, and ground to pass through a $1 \mathrm{~mm}$ screen for later analysis of the dry matter (DM), crude protein $(\mathrm{CP})$, organic matter $(\mathrm{OM})$, ether extract (EE) and acid detergent fiber (ADF), according to AOAC (Association..., 1990) methods. In the analysis of neutral detergent 
fiber (NDF) the samples were treated with heatstable alpha-amylase, without sodium-sulfite, and corrected for ash and nitrogenous compounds [aNDFom(n)] (Mertens, 1992). The correction of NDF and ADF for nitrogenous compounds and the estimation of the contents of insoluble nitrogenous compounds in neutral (NDIN) and acid (ADIN) detergents were made according to Licitra et al. (1996). Lignin (LIG) contents were obtained through solubilization of cellulose with sulfuric acid (Van Soest and Robertson, 1985).

The non-fibrous carbohydrate (NFC) contents from the DM of the by-products were calculated according to Hall (2000) as 100 - NDF - CP $\mathrm{EE}-\mathrm{ash}(\mathrm{g} / \mathrm{kg}$ in the DM). The contents of available crude protein (ACP) were claculated as $(\mathrm{CP}-\mathrm{ADIN} \times$ 6.25). TDN at maintenance values were estimated according to equations recommended by NRC (National..., 2001).

Glass test tubes were used for incubation according to procedures described by Schofield et al. (1994). The $50 \mathrm{~mL}$ glass test tubes were previously washed with distilled water and dried in a sterilizer. Approximately $200 \mathrm{mg}$ of substrate (residue to be studied) were subsequently placed in the tubes in three replicates. The buffer solution, as described by Menke and Steingass (1988), was prepared and placed in a water bath at $39^{\circ} \mathrm{C}$ under continuous flushing with $\mathrm{CO}_{2}$.

Rumen fluid was manually collected before the morning feeding, stored in insulated flasks, which were preheated at $39^{\circ} \mathrm{C}$, and then immediately taken to the laboratory. In the acclimatized room of the laboratory, also at $39^{\circ} \mathrm{C}$, the rumen fluid was filtered through four layers of cheese-cloth (gauzes) and subsequently added $(1: 2 \mathrm{v} / \mathrm{v})$ to the buffered solution under continuous flushing with $\mathrm{CO}_{2}$.

Three test tubes per residue were prepared with $30 \mathrm{~mL}$ of the buffered rumen fluid added to the substrate and immediately sealed with rubber corks and aluminum rings to ensure complete maintenance of gases inside.

Following 48 hours of incubation, the test tubes were removed from the acclimatized room and refrigerated at $4^{\circ} \mathrm{C}$ to halt the fermentation process. The contents of each test tube were filtered in a Gooch crucible (porosity 0), washed with warm distilled water and acetone. Subsequently $30 \mathrm{~mL}$ of neutral detergent solution were added to each test tube (Mertens, 2002); the test tubes were sterilized for 60 minutes at $105^{\circ} \mathrm{C}$ according to the technique proposed by Pell and Schofield (1993); the contents of each test tube were filtered in a Gooch crucible (porosity 0), washed with warm distilled water and acetone, and dried in a sterilizer at $105^{\circ} \mathrm{C}$ for 16 hours.

Cluster analysis was used to assess the divergence in nutritional value of by-products based on the discriminatory variables included (Johnson and Wichern, 1988). Specifically, the average Euclidean distance between standardized variables was used to measure the disimilarity and the minimum variance. PROC UNIVARIATE by SAS (Statistical, 2000) was used for analysis of descriptive statistics and for cluster analyses we used PROC CLUSTER, METHOD=WARD by SAS (Statistical..., 2000).

\section{RESULTS}

The chemical composition, IVNDFD and TDN of fifty-seven by-products is found in Table 1 . Based on the discriminatory variables (IVNDFD and TDN) and on the dissimilarity expressed by the average Euclidean distance between variables, a new set of variables establishing hierarchy levels and clustering of the 57 byproducts into two distinct groups was created, such that homogeneity was greatest within each group and heterogeneity was greatest across the groups.

Descriptive statistics for IVNDFD and TDN are listed in Table 2, other than the distribution of the 57 agricultural and agro-industrial byproducts. There was an efficiency in the clustering obtained with the discriminatory variables (IVNDFD and TDN), even though IVNDFD in G1 group presented as heterogeneous with the highest variation coefficient $(45.7 \%)$ when all other variables presented variation coeficients below $16.1 \%$.

On average, the by-products belonging to G1 contained $425 \mathrm{~g} / \mathrm{kg}$ DM (SD 194) of IVNDFD and $388 \mathrm{~g} / \mathrm{kg}$ TDN (SD 62) respectively.With $17.5 \%$ of all by-products clustered, those belonging to $\mathrm{G} 1$ can be better visualized from the behavior of the dissimilarity dendogram established (Figure 1). 
Nutritional diversity of agricultural...

Table 1. Chemical composition, in vitro neutral detergent fiber digestibility (IVNDFD) and total digestible nutrients (TDN) of by-products

\begin{tabular}{|c|c|c|c|c|c|c|c|c|c|c|c|c|}
\hline Residue & $\underset{\mathrm{a}}{\mathrm{DM}}$ & $\underset{b}{\mathrm{OM}}$ & $\underset{\mathrm{b}}{\mathrm{CP}}$ & $\underset{c}{\operatorname{NDIN}}$ & $\underset{\mathrm{c}}{\mathrm{ADIN}}$ & $\underset{b}{\mathrm{EE}}$ & $\underset{\mathrm{b}}{\operatorname{aNDF}(\mathrm{n})}$ & $\underset{b}{\mathrm{NFC}}$ & $\underset{\mathrm{b}}{\mathrm{ADF}(\mathrm{n})}$ & $\underset{b}{\mathrm{LIG}}$ & $\underset{\mathrm{a}}{\mathrm{IVNDF}}$ & $\underset{\mathrm{a}}{\mathrm{TDN}}$ \\
\hline African oil meal & 924 & 970 & 161 & 949 & 583 & 107 & 523 & 179 & 266 & 112 & 651 & 530 \\
\hline Barbados cherry juice & 171 & 971 & 85 & 627 & 26 & 17 & 493 & 376 & 451 & 167 & 607 & 521 \\
\hline $\begin{array}{l}\text { residue } \\
\text { Brewer residue }\end{array}$ & 264 & 959 & 345 & $\begin{array}{l}621 \\
589\end{array}$ & $\begin{array}{c}26 \\
559\end{array}$ & $\begin{array}{l}17 \\
92\end{array}$ & $\begin{array}{l}493 \\
331\end{array}$ & $\begin{array}{l}3 / 0 \\
192\end{array}$ & $\begin{array}{l}451 \\
138\end{array}$ & 87 & 601 & $\begin{array}{l}521 \\
580\end{array}$ \\
\hline Carrot discard human residue & 89 & 913 & 124 & 151 & 106 & 12 & 141 & 636 & 138 & 1 & 953 & 780 \\
\hline Carrot leaf & 226 & 638 & 145 & 762 & 634 & 10 & 75 & 408 & 311 & 91 & 822 & 446 \\
\hline Carrot shaving & 87 & 894 & 112 & 321 & 273 & 27 & 186 & 570 & 181 & 15 & 939 & 715 \\
\hline Carrot thick residue & 85 & 881 & 147 & 827 & 228 & 20 & 137 & 578 & 206 & 26 & 933 & 701 \\
\hline Cassava flower processing & 439 & 988 & 30 & 550 & 146 & 9 & 15 & 935 & 32 & 6 & 982 & 881 \\
\hline Cassava foliage & 219 & 918 & 242 & 598 & 560 & 24 & 404 & 248 & 227 & 96 & 709 & 523 \\
\hline Cassava hull & 256 & 966 & 37 & 588 & 74 & 6 & 158 & 766 & 153 & 55 & 872 & 757 \\
\hline Cassava hull dirty & 250 & 953 & 34 & 647 & 362 & 2 & 208 & 710 & 246 & 126 & 672 & 670 \\
\hline Cassava hull thread & 266 & 919 & 34 & 547 & 277 & 11 & 127 & 747 & 246 & 88 & 734 & 706 \\
\hline Cassava leaf & 219 & 929 & 215 & 669 & 406 & 40 & 303 & 371 & 201 & 110 & 746 & 581 \\
\hline Cassava shaving & 918 & 949 & 29 & 242 & 160 & 12 & 175 & 732 & 202 & 43 & 875 & 744 \\
\hline Cassava stalk & 900 & 963 & 54 & 472 & 213 & 9 & 651 & 248 & 560 & 200 & 321 & 412 \\
\hline Castor bran & 915 & 914 & 397 & 263 & 243 & 25 & 360 & 132 & 294 & 262 & 608 & 453 \\
\hline Castor detoxicated bran & 906 & 924 & 405 & 420 & 38 & 24 & 346 & 149 & 424 & 313 & 579 & 496 \\
\hline Citrus pulp & 859 & 943 & 64 & 587 & 277 & 21 & 206 & 652 & 192 & 27 & 922 & 742 \\
\hline Cocoa eed hull & 893 & 926 & 143 & 551 & 475 & 51 & 370 & 362 & 333 & 185 & 680 & 499 \\
\hline Cocoa meal & 947 & 909 & 159 & 945 & 326 & 166 & 190 & 394 & 230 & 106 & 756 & 637 \\
\hline Coffee hull & 905 & 924 & 117 & 366 & 229 & 10 & 571 & 225 & 458 & 175 & 619 & 425 \\
\hline Coffee parchment & 917 & 988 & 37 & 326 & 247 & 7 & 905 & 39 & 728 & 227 & 163 & 311 \\
\hline Cotton bran & 905 & 955 & 265 & 171 & 102 & 20 & 516 & 154 & 406 & 96 & 709 & 564 \\
\hline Cotton seed & 930 & 958 & 205 & 74 & 62 & 182 & 416 & 154 & 344 & 74 & 620 & 635 \\
\hline Cracked bean & 872 & 955 & 239 & 358 & 254 & 20 & 295 & 402 & 6 & 2 & 996 & 766 \\
\hline Cracker meal & 902 & 978 & 104 & 351 & 14 & 174 & 57 & 642 & 16 & 4 & 960 & 866 \\
\hline Genipap juice residue & 136 & 965 & 47 & 658 & 556 & 4 & 469 & 445 & 342 & 51 & 812 & 644 \\
\hline Grape wine residue & 892 & 937 & 121 & 861 & 502 & 74 & 458 & 285 & 393 & 315 & 521 & 398 \\
\hline Guava juice residue & 286 & 986 & 86 & 268 & 189 & 77 & 730 & 94 & 581 & 221 & 360 & 383 \\
\hline Jack fruit & 342 & 925 & 108 & 830 & 444 & 34 & 427 & 356 & 387 & 19 & 792 & 666 \\
\hline Jack fruit silage & 278 & 960 & 83 & 381 & 159 & 17 & 161 & 698 & 97 & 36 & 917 & 765 \\
\hline Mango hull & 204 & 976 & 42 & 974 & 227 & 40 & 366 & 528 & 227 & 59 & 771 & 683 \\
\hline Mango internal seed & 512 & 980 & 55 & 756 & 140 & 78 & 256 & 591 & 38 & 16 & 966 & 787 \\
\hline Mango juice residue & 345 & 976 & 51 & 792 & 226 & 40 & 326 & 560 & 226 & 73 & 753 & 681 \\
\hline Mango outward seed & 349 & 972 & 21 & 565 & 255 & 7 & 674 & 271 & 606 & 136 & 392 & 481 \\
\hline Manufactures of soap (palm) & 945 & 943 & 201 & 760 & 244 & 115 & 533 & 94 & 465 & 280 & 518 & 380 \\
\hline Palm meal & 929 & 976 & 121 & 866 & 225 & 164 & 628 & 63 & 539 & 83 & 629 & 565 \\
\hline Papaya juice residue & 101 & 949 & 148 & 869 & 274 & 73 & 294 & 435 & 287 & 77 & 961 & 652 \\
\hline Papaya seed & 802 & 929 & 259 & 902 & 723 & 229 & 156 & 284 & 134 & 75 & 929 & 642 \\
\hline Papaya without seed & 881 & 936 & 133 & 522 & 51 & 21 & 120 & 662 & 161 & 44 & 676 & 754 \\
\hline Passion fruit & 195 & 963 & 100 & 180 & 77 & 122 & 548 & 194 & 419 & 78 & 687 & 591 \\
\hline Peach palm & 865 & 950 & 60 & 243 & 118 & 13 & 578 & 299 & 389 & 30 & 714 & 643 \\
\hline Pearl millet & 892 & 984 & 178 & 851 & 426 & 39 & 205 & 563 & 12 & 12 & 946 & 787 \\
\hline Pineapple crown & 140 & 922 & 91 & 115 & 60 & 15 & 522 & 293 & 266 & 33 & 783 & 626 \\
\hline Pineapple hull & 95 & 959 & 66 & 453 & 80 & 5 & 509 & 381 & 247 & 27 & 830 & 678 \\
\hline Pineapple juice residue & 139 & 953 & 71 & 505 & 444 & 8 & 602 & 272 & 310 & 37 & 811 & 616 \\
\hline Protein bran & 858 & 942 & 219 & 382 & 133 & 28 & 227 & 468 & 96 & 14 & 910 & 754 \\
\hline Pumpkin seed & 173 & 956 & 176 & 359 & 271 & 20 & 196 & 564 & 141 & 33 & 946 & 740 \\
\hline Radish biofuel residue & 916 & 943 & 276 & 199 & 187 & 243 & 227 & 197 & 145 & 75 & 816 & 676 \\
\hline Rice hull & 919 & 839 & 21 & 917 & 599 & 7 & 691 & 120 & 751 & 199 & 91 & 275 \\
\hline Soursop juice residue & 260 & 977 & 104 & 421 & 283 & 131 & 378 & 365 & 311 & 72 & 826 & 660 \\
\hline Soybean hull & 922 & 956 & 120 & 696 & 254 & 4 & 675 & 156 & 454 & 16 & 928 & 646 \\
\hline Sunflower biofuel residue & 927 & 949 & 369 & 118 & 56 & 21 & 186 & 372 & 113 & 52 & 882 & 730 \\
\hline Tamarind juice residue & 466 & 975 & 131 & 388 & 340 & 26 & 531 & 286 & 252 & 117 & 738 & 544 \\
\hline Uricury bran & 891 & 969 & 138 & 791 & 464 & 48 & 683 & 100 & 557 & 234 & 657 & 356 \\
\hline Wild cabbage residue & 806 & 914 & 184 & 486 & 227 & 11 & 257 & 462 & 210 & 22 & 946 & 699 \\
\hline Wild cabbage stalk & 77 & 858 & 183 & 402 & 239 & 11 & 316 & 348 & 233 & 45 & 900 & 591 \\
\hline
\end{tabular}

${ }^{\mathrm{a}} \mathrm{g} / \mathrm{kg} ;{ }^{\mathrm{b}} \mathrm{g} / \mathrm{kg}$ in DM; ${ }^{\mathrm{g}} \mathrm{kgg}$ in CP

Dry matter (DM); organic matter (OM); crude protein (CP); neutral detergent insoluble nitrogen (NDIN); acid detergent insoluble nitrogen (ADIN); ether extract (EE); neutral detergent fiber expressed exclusive of ash and nitrogenous compounds [aNDFom(n)]; non-fibrous carbohydrate (NFC); acid detergent fiber expressed exclusive of nitrogenous compounds (ADF(n)); lignin (LIG); in vitro neutral detergent fiber digestibility (IVNDFD); total digestible nutrients (TDN). 
Table 2. Descriptive statistics and distributions of two groups formed from the discriminate analysis of by-products

\begin{tabular}{lccccc}
\hline Variables & Mean & SD & Minimum & Maximum & CV (\%) \\
\hline Group 1 & 425 & 194 & 91 & 657 & 45.7 \\
Group 2 & 814 & 119 & 579 & 996 & 14.7 \\
& & & TVNDFD, g/kg DM & \\
Group 1 & 388 & 62 & 275 & 481 & 16 \\
Group 2 & 663 & 97 & 446 & 881 & 14.7 \\
\hline
\end{tabular}

In vitro neutral detergent fiber digestibility (IVNDFD); total digestible nutrients (TDN).

Group 1 = Cassava stalk, castor bran, coffee hull, coffee parchment, grape, guava, mango seed outward, manufactures of soap (palm), Rice hull, uricury bran.

Group 2 = African meal, barbados cherry, brewer residue, carrot discard from human residue, carrot leaf, carrot shaving, carrot thick residue, cassava dirty hull, cassava flower processing, cassava foliage, cassava hull of the thread, cassava hull, cassava leaf, cassava shaving, castor detoxicated bran, citrus pulp, cocoa bran, cocoa seed hull, cotton bran, cotton seeds, cracked meal, cracker, genipap, jack fruit silage, jack fruit, mango fruit from juice industry residue, mango hull, mango internal seed, palm, papaya fruit from juice industry residue, papaya seed, papaya without seed, passion fruit from juice industry residue, peach palm, pearl millet, pineapple crown, pineapple hull, pineapple, protein bran corn, pumpkin, radish biofuel residue, soybean hull, sunflower biofuel residue, tamarind fruit from juice industry residue, wild cabbage residue, wild cabbage stalk.



Figure 1. Dissimilarity dendogram of the nutritional value between 10 by-products.

The two subgroups were formed by considering $48 \%$ of the dissimilarity due to the short distance between the melting points of the groups by performing a section of the dendrogram as presented in Figure 1, carried out subjectivly according to Johnson and Wichern (1988). In these two subgroups, by-products of rice hull and parchment coffee were hierarchically clustered in a different subgroup compared to the other G1 by-products since they exhibited low IVNDFD and TDN values (Table 1).

Clustering techniques minimize the variability within a group. However, if the estimate of the distance between pairs of individuals within a group is high, sub-clustering is justified (Abreu et al., 2004). Due to the large number of discriminatory variables, sub-clustering better stratifies the by-products of G2. As the byproducts of $\mathrm{G} 2$ represented $82.5 \%$ of all the byproducts studied, a new cluster analysis was performed using the following as discriminatory variables: ACP, EE, NFC, aNDFom(n), LIG, IVNDFD, and TDN (Figure 2). Subsequently, this hypothesized section in the dendogram of dissimilarity improved the characterization of G2 through the formation of six subgroups (SG1 to SG6). 
Nutritional diversity of agricultural...

Average Euclidean distance

$\begin{array}{lllllllllll}3.14 & 467 & 621 & 7.75 & 928 & 1082 & 1236 & 13.89 & 15.43 & 1697 & 1850\end{array}$

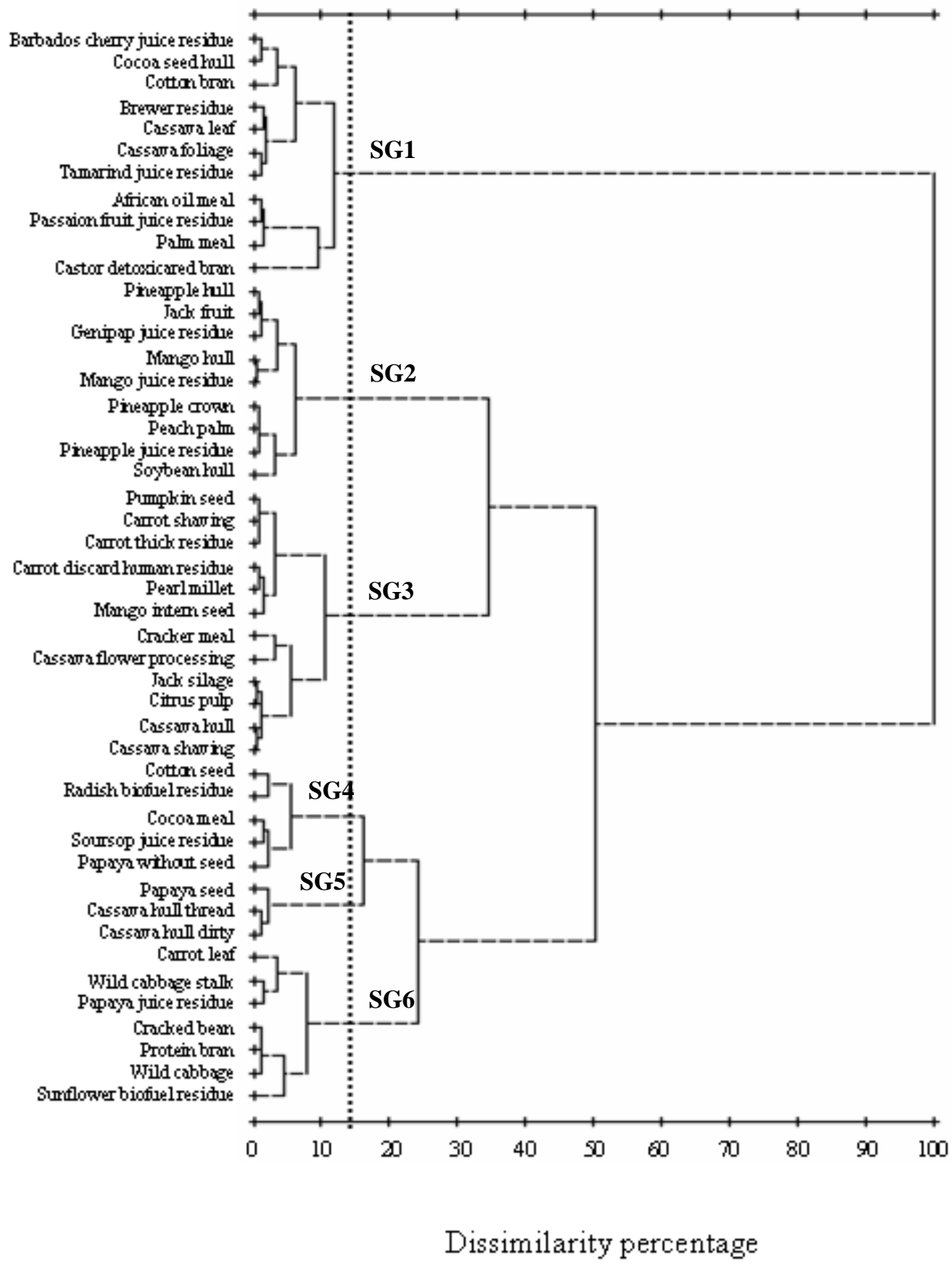

Figure 2. Dissimilarity dendogram of the nutritional value of 47 by-products. 
Although SG1 by-products had the second highest average protein values amongst the subgroups, and the highest content of ACP (castor bean detoxicated with $389 \mathrm{~g} / \mathrm{kg}$ of ACP in DM), they also had the highest and the lowest value, respectively, for LIG and TDN (Table 1). SG1 was the most heterogeneous subgroup, which had by-products with the highest average Euclidean distance of 4.23 (Figure 2). However, the discriminatory variable that most influenced the cluster analysis was TDN, which was substantiated by the coefficient of variation $(\mathrm{CV})$ of $6.16 \%$ obtained by the same subgroup (Table 1). SG2 by-products had the highest average values of aNDFom(n) and values greater than 600 and $700 \mathrm{~g} / \mathrm{kg}$ of TDN and IVNDFD, respectively (Table 1). SG3 by-products had the highest average values for TDN $(772 \mathrm{~g} / \mathrm{kg})$ and IVNDFD $(934 \mathrm{~g} / \mathrm{kg})$ and the lowest average value for $\mathrm{LIG}(23 \mathrm{~g} / \mathrm{kg}$ in DM). Among the discriminatory variables, EE content mostly influenced the hierarchical grouping of byproducts in SG4 (Table 1).

The three by-products of SG5 were very homogeneous and had the highest concentration of NFC. The main characteristic that distinguished SG5 was lower values of IVNDFD. However, the by-products of this subgroup are essentially energy. Differently from the other subgroups, SG6 by-products had the highest average ACP value, suggesting their use as protein concentrates (Table 1).

\section{DISCUSSION}

The low digestibility of NDF in the by-products of $\mathrm{G} 1$ for rice hull and parchment coffee was mainly due to the high concentration of LIG, as LIG is one of the main limiting factors of fibrous carbohydrate digestion (Jung and Allen, 1995).

In addition to the factors inherent in the chemical composition of the fiber fraction and in addition to LIG operating as the main limiting factor in the availability of its chemical contents, other factors also interfere with a better usage of the nutritional value of the other by-products of G1.

In general, the by-products belonging to SG1 group had high aNDFom(n) values, which resulted in lower energy content. Due to the high degree of association of aNDFom(n) to LIG, a lower residue availability was observed, thus reducing the fraction of the feed that could potentially be digestible.

In our present study, all SG1 by-products had TDN values below $600 \mathrm{~g} / \mathrm{kg}$ and NDFap values greater than $300 \mathrm{~g} / \mathrm{kg}$ in DM. This finding is supported by results from other researches that have already tested the by-products classified in our SG1 as roughages.

Modesto et al. (2008) concluded that up to $600 \mathrm{~g} / \mathrm{kg}$ of cassava foliage silage can be substituted for corn silage in the diets of nonlactating cows without modifing consumption, ruminal parameters, or nutrional digestibility. Cabral Filho et al. (2007), evaluating possible alterations in feed intake and digestibility by substituting an exclusively hay only diet with wet brewer's grain (a silage by-product) in sheep, observed that the inclusion of $330 \mathrm{~g} / \mathrm{kg}$ of this by-product stored based on DM improved the digestibility of the diet and thereby demonstrated the usefulness of this feed resource.

As can be seen in Table 1, all representative byproducts of SG2 had CP values below $200 \mathrm{~g} / \mathrm{kg}$ in the DM, and, in spite of having NDFap values greater than $320 \mathrm{~g} / \mathrm{kg}$, all can be considered partial energy concentrate substitutes.

Among the SG2 by-products, the soybean hull obtained from soybean milling has been greatly highlighted in the national scenery due to high Brazilian soybean production. The soybean hull represents $70-80 \mathrm{~g} / \mathrm{kg}$ of the bean's weight (Restle et al., 2004). Due to its high NDF content, the soybean hull was initially evaluated as a roughage substitute in diets (Azevedo, 1998). However, results confirming the high digestibility of NDF in this residue led to studies of the use of soybean hull as a substitute for cereal bran in the concentrated fraction of the diet (Bach et al., 1999).

Animals that receive diets containing soybean hull, partially substituting for corn or sorghum, have demonstrated high levels of diet fiber digestion (Mendes et al., 2005) and have demonstrated improvement in weight gain and feed conversion (Restle et al., 2004). Additionally, this residue resulted in high production of volatile fatty acids (Bach et al., 
1999) and in ideal $\mathrm{pH}$ supporting the action of ruminal microorganisms (Ludden et al., 1995).

Since high energy contributions supporting ruminal microorganisms were found for SG3 byproducts, a protein source of compatible degradation rate should be considered when formulating diets with these by-products. Synchronization of energy fermentation and $\mathrm{CP}$ degradation is essential for efficient use of energy and protein by ruminal microorganisms.

Assis et al. (2004), substituting corn meal for citrus pulp in the diet of milking cows, observed that the apparent digestibility of the nutrients did not vary with the substitution. The authors explained their finding as a result of the high degradability of citrus pulp fiber preventing differences in the digestibility of the nutrients.

Studies conducted by Milton and Brandt (1993) and Passini et al. (2001) have shown that $300 \mathrm{~g} / \mathrm{kg}$ of crack meal can be substituted for corn in ruminant diets. However, since this residue in our present study presented $174 \mathrm{~g} / \mathrm{kg}$ of $\mathrm{EE}$ in DM (Table 1), it is advised that attention be paid to EE content of any diet. As dietary proportion of lipids exceeds $60 \mathrm{~g} / \mathrm{kg}$ in DM, they may cause negative effects on ruminal environment, including reduction in fiber digestibility (Palmquist and Jenkins, 1980).

Care should be taken with all by-products in SG4 as this subgroup demonstrated the highest average value of $\mathrm{EE}$ with soursop juice residue possessing the lowest value (131 g/kg in DM).

In a study that compared levels of $0,120,180$ and $240 \mathrm{~g} / \mathrm{kg}$ of cotton seed in feedlot diets, Brosh et al. (1989) concluded that this residue caused a reduction in weight gain without a change in DM intake. Ludovico and Mattos (1997) observed a quadratic effect of cotton seed (i.e., 0, 100, 200 or $300 \mathrm{~g} / \mathrm{kg}$ ) on DM intake in cows on sugar cane and cotton seed diets. Cooke et al. (2007) reported that diets containing cotton seed did not affect DM intake or milk production, but they did reduce milk fat content due to reduced unsaturated lipids. Therefore, it is suggested that the use of SG4 by-products be limited due to their EE concentration.

Several of the SG5 by-products with NFC concentrations of $707 \mathrm{~g} / \mathrm{kg}$ in $\mathrm{DM}$ have been tested as partial substitutes for energy concentrates. Marques et al. (2000), studying the effect of cassava hull as a substitute for corn, observed that, although cassava hull reduced DM intake, it did not alter weight gain, feed conversion, or income from the animals' carcasses. However, they suggest caution with the substitution to avoid problems with intake and acidosis.

With average CP values of $212 \mathrm{~g} / \mathrm{kg}$ in DM, SG6 by-products have been evaluated as partial substitutes for protein concentrates (Table 1). Studies involving young ruminants and milking cows have indicated that the nutritional value of sunflower meal is equivalent to soybean and cotton meal (Vincent et al., 1990; Milton et al., 1997). Macedo et al. (2003), substituting soybean meal for corn gluten, observed a reduction in the production of milk, fat, NDF intake, and plasmatic urea levels.

Considering that soybean meal is the main and most used protein ingredient in ruminant rations, limitations on partial substitution should be imposed due to soybean meal offerring a better biological protein value when compared to other by-products, which are typically inferior due to their inbalance of essential amino acids. Additional factors such as low palatability and low digestibility of the cracked beans should also be considered.

As can be seen in Table 1, the lowest $\mathrm{CP}$ value among SG6 by-products was for carrot leaf at $145 \mathrm{~g} / \mathrm{kg}$ in DM. Carrot and wild cabbage byproducts have high mineral content, resulting in ash in DM values of 362 and $142 \mathrm{~g} / \mathrm{kg}$, respectively.

\section{CONCLUSION}

Results support the hypothesis that the byproducts belonging to G1 had limited characteristics for their use in animal feeding. The SG1 by-products could preferably be used as partial roughage substitutes. The by-products of subgroups SG2, SG3, SG4, and SG5 could be used as partial energy concentrate substitutes, and the SG6 by-products could be used as partial protein concentrate substitutes. 


\section{REFERENCES}

ABREU, F.B.; LEAL, N.R.; RODRIGUES, R. et al. Divergência genética entre acessos de feijão-de-vagem de hábito de crescimento indeterminado. Hort. Bras., v.22, p.547-552, 2004.

ASSIS, A.J.; CAMPOS, J.M.S.; QUEIROZ, A.C. et al. Polpa cítrica em dietas de vacas em lactação. 2. Digestibilidade dos nutrientes em dois períodos de coleta de fezes, $\mathrm{pH}$ e nitrogênio amoniacal do líquido ruminal. Rev. Bras. Zootec., v.33, p.251-257, 2004.

ASSOCIATION of official analytical chemistry AOAC. Official Methods of Analysis, 15.ed. Arlington: AOAC International. 1990.

AZEVEDO, P.S. A casca do grão de soja em substituição ao feno de gramíneas nas rações com diferentes fontes proteicas para bovinos. 1998. 53f. Tese (Doutorado). Universidade Estadual Paulista, Jaboticabal, SP.

BACH, A.; YOON, I.K.; STERN, M.D. et al. Effects of type of carbohydrate supplementation to lush pasture on microbial fermentation in continuous culture. J. Dairy Sci., v.82, p.153160, 1999.

BROSH, A.; HOLZER, Z.; LEVY, D. Cottonseed for protein and energy supplementation of high - roughage diets for beef cattle. Anim. Prod., v.48, p.513-518, 1989.

CABRAL FILHO, S.L.S.; BUENO, I.C.S.; ABDALLA, A.L. Substituição do feno de tifton pelo resíduo úmido de cervejaria em dietas de ovinos em mantença. Cienc. Anim. Bras., v.8, p.65-73, 2007.

CIEGLINSKI, A. PIB do agronegócio em 2007 bate recorde, com crescimento de 7,89\%.. Brasília: Agência Brasil, 2008. Disponível em: http://agenciabrasil.ebc.com.br/noticia/2008-0319/pib-do-agronegocio-em-2007-bate-recordecom-crescimento-de-789. Acesso em: 19 mar. 2008.
CONSELHO Nacional de Desenvolvimento Científico e Tecnológico - CNPq. Apoio ao Desenvolvimento de Tecnologias para Redução e Utilização de Resíduos Rurais e Agroindustriais e Redução das Perdas na Produção Agropecuária. Edital CT-AGRO/MCT/CNPq n.08/2005. Lançamento do edital no D.O.U.. Brasília, 29 mar. 2005.

COOKE, K.M.; BERNARD, J.K.; WILDMAN, C.D. et al. Performance and ruminal fermentation of dairy cows fed whole cottonseed with elevated concentrations of free fatty acids in the oil. J. Dairy Sci., v.90, p.2329-2334, 2007.

HALL, M.B. Neutral Detergent-Soluble Carbohydrates. Nutritional Relevance and Analysis., Gainesville: University of Florida, 2000.77p.

JOHNSON, R.A.; WICHERN, D.W. Applied multivariate statistical analysis. 2nd. ed. Wisconsin: Prentice Hall, 1988. 607p.

JUNG, H.G.; ALLEN, M.S. Characteristics of plant cell wall affecting intake and digestibility of forages by ruminants. J. Anim. Sci., v.73, p.2774-2790, 1995.

LICITRA, G.; HERNANDEZ, T.M.; VAN SOEST, P.J. Standardization of procedures for nitrogen fractionation of ruminant feeds. Anim. Feed Sci. Technol., v.57, p.347-358, 1996.

LUDDEN, P.A.; CECAVA, M.J.; HENDRIX, K.S. The value of soybean hulls as a replacement for corn in beef cattle diets formulated with or without added fat. J. Anim. Sci., v.73, p.27062711, 1995.

LUDOVICO, A.; MATTOS, W.R.S. Avaliação de dietas à base de cana-de-açúcar (Saccharum officinarum L.) e diferentes níveis de semente de algodão (Gossypium hirsutum L.). Rev. Bras. Zootec., v.26, p.403-410, 1997.

MACEDO, L.G.P.; DAMASCENO, J.C.; MARTINS, E.N. et al. Substituição do farelo de soja pela farinha de glúten de milho na alimentação de cabras leiteiras. Rev. Bras. Zootec., v.32, p.992-1001, 2003. 
MARQUES, J.A.; PRADO, I.N.; ZEOULA, L.M. et al. Avaliação da mandioca e seus resíduos industriais em substituição ao milho no desempenho de novilhas confinadas. Rev. Bras. Zootec., v.29, p.1528-1536, 2000.

MENDES, A.R.; EZEQUIEL, J.M.B.; GALATI, R.L. et al. Consumo e digestibilidade total e parcial de dietas utilizando farelo de girassol e três fontes de energia em novilhos confinados. Rev. Bras. Zootec., v.34, p.679-691, 2005.

MENKE, K.H.; STEINGASS, H. Estimation of the energetic feed value obtained from chemical analysis and gas production using rumen fluid. Anim. Res. Dev., v.28, p.7-55, 1988.

MERTENS, D.R. Analysis of fiber in feeds and its use in feed evaluation and ration formulation. In: SIMPÓSIO INTERNACIONAL DE RUMINANTES, 1992, Lavras. Anais... Lavras: Sociedade Brasileira de Zootecnia, 1992. p.1-32.

MERTENS, D.R. Gravimetric determination of amylase-treated neutral detergent fiber in feeds with refluxing in beakers or crucibles: collaborative study. J. AOAC Int., 85, p.12171240, 2002

MILTON, C.T.; BRANDT, R.T. Utilization of dried bakery product by finishing beef steers. Kentucky: Cattlemen's Day, 1993. v.1, p.104106.

MILTON, C.T.; BRANDT JR.R.T.; TITGEMEYER, E.C. et al. Effect of degradable and escape protein and roughage type on performance and carcass characteristics of finishing yearling steers. J. Anim. Sci., v.75, p.2834-2840, 1997.

MODESTO, E.C.; SANTOS, G.T.; ZAMBOM, M.A. et al. Consumo, digestibilidade $\mathrm{e}$ parâmetros ruminais em vacas gestantes alimentadas com silagem de rama de mandioca. Rev. Bras. Zootec., v.37, p.944-950, 2008.

NATIONAL research council - NRC. Nutrient requirements of dairy cattle. 7.ed. Washington, DC: National academic press, 2001. 381p.
OLTJEN, J.W.; BECKETT, J.L. Role of ruminant livestock in sustainable agricultural systems. J. Anim. Sci, v.74, p.1406-1409, 1996.

PALMQUIST, D.L.; JENKINS, T.C. Fat in lactation rations: review. J. Dairy Sci., v.63, p.114,1980 .

PASSINI, R.; SPERS, A.; LUCCI, C.S. Efeitos da substituição parcial do milho na dieta pelo resíduo de panificação sobre o desempenho de novilhos da raça Holandesa. Pesq. Agropec. Bras., v.36, p.689-694, 2001.

PELL, A.N.; SCHOFIELD, P. Computerized monitoring of gas production to measure forage digestion in vitro. J. Dairy Sci., v.76, p.10631073, 1993.

RESTLE, J.; FATURI, C.; ALVES FILHO, D.C. et al. Substituição do grão de sorgo por casca de soja na dieta de novilhos terminados em confinamento. Rev. Bras. Zootec., v.33, p.10091015, 2004.

SAVY FILHO, A.; BENZATTO, N.V. O mercado está para a mamona. Cas. Agric., v.5, p.12-15, 1983.

SCHOFIELD, P.; PITT, R.E.; PELL, A.N. Kinetic of fiber digestion from in vitro gas production. J. Anim. Sci., v.72, p.2980-2991, 1994.

STATISTICAL Analysis Sistem. SAS/STAT User's guide, Version 8. SAS Institute Inc., Cary, NC. 2000.

VAN SOEST, P.J.; ROBERTSON, J.B. Analysis of forages and fibrous foods. Ithaca: Cornell University, 1985. 202p.

VINCENT, I.C.; HILL, R.; CAMPLING, R.C. A note on the use of rapeseed, sunflower and soyabean meals as protein sources in compound foods for milking cattle. Anim. Prod., v.50, p.541-543, 1990. 